\title{
Cutaneous melanoma in Latin America: the need for more data
}

\author{
Rafael A. Schmerling, ${ }^{1}$ Dora Loria, ${ }^{2}$ Gabriela Cinat, ${ }^{2}$ \\ Wilmer E. Ramos, ${ }^{3}$ Andrés F. Cardona, ${ }^{4}$ Jorge L. Sánchez, ${ }^{5}$ \\ Hector Martinez-Said ${ }^{6}$ and Antonio C. Buzaid ${ }^{1}$
}

Suggested citation Schmerling RA, Loria D, Cinat G, Ramos WE, Cardona AF, Sánchez JL, et al. Cutaneous melanoma in Latin America: the need for more data. Rev Panam Salud Publica. 2011;30(5):431-8.

ABSTRACT Objective. To identify the scientific literature on cutaneous melanoma in Latin America and compile all available epidemiologic data to demonstrate the need for reliable regional and country-specific data on incidence and mortality estimates.

Methods. Literature searches were conducted in PubMed, Embase, LILACS, and Google Scholar databases for epidemiologic studies from 1 January 2000 to 31 October 2010 related to melanoma in Argentina, Brazil, Colombia, Mexico, Puerto Rico, and Venezuela. A final search on melanoma cases was carried out using country-specific population-based cancer registries. No statistical analyses were conducted.

Results. For all six countries, most epidemiological research on cutaneous melanoma consists of hospital-based or case-control studies. Very few studies report incidence and mortality rates. Attempts to estimate disease rates have relied on national incidence and mortality data and information extracted from cancer registries. While predominance of European ancestry is a known risk factor for developing melanoma, the association of melanoma and ethnicity is not well-documented in some of the populations reviewed. Latin Americans are frequently exposed to ultraviolet (UV) radiation due to the tropical weather, high altitude, and thinning ozone layer in some regions. Tanned skin is viewed as healthy and beautiful. While melanoma public health campaigns have been under way in Latin America for decades, increasing melanoma awareness remains imperative.

Conclusions. There is an urgent need to collect accurate epidemiologic melanoma data in Latin America. Future research in the region should include more comprehensive, countryspecific, population-based studies to allow for comparative evaluation of incidence and mortality rates.

Key words Melanoma; skin neoplasms; information systems; mortality; incidence; risk; Argentina; Brazil; Colombia; Mexico; Puerto Rico; Venezuela; Latin America.

1 Centro de Oncologia do Hospital São José, São Paulo, SP, Brazil. Send correspondence to: Rafael A. Schmerling, schmerling@me.com

2 Instituto de Oncología "Ángel H. Roffo," Universidad de Buenos Aires, Buenos Aires, Argentina.

3 Instituto Docente de Urología, Universidad de Carabobo, Valencia, Venezuela.

4 Instituto de Oncología, Fundación Santa Fe de Bogotá, Bogotá, Colombia.

5 Hospital Oncológico “Dr. Isaac González Martínez," San Juan, Puerto Rico.
Melanoma represents a challenge for individual patient and public health care systems around the world. Melanoma cases are increasing more rapidly than any other cancer, particularly in populations of European origin. A rela-

\footnotetext{
6 Instituto Nacional de Cancerología, Mexico City Mexico.
}

tively high incidence is thus expected in regions with extensive European immigration, such as Latin America. Because optimal prognosis coincides with early diagnosis and proper treatment $(1,2)$, national planning and policies to improve public awareness, early detection, and the dissemination of improved treatment options, supported by 
the best available epidemiological data, are essential. However, few incidence and prevalence data exist for melanoma in Latin America. The objective of this study was to identify the scientific literature on cutaneous melanoma in Latin America and compile all available epidemiologic data to demonstrate the need for reliable regional and countryspecific data on incidence and mortality estimates.

\section{MATERIALS AND METHODS}

Literature searches were performed in PubMed, Embase, LILACS, and Google Scholar databases for epidemiologic studies related to melanoma in Latin America overall and the following countries specifically: Argentina, Brazil, Colombia, Mexico, Puerto Rico, and Venezuela. The first literature search, using PubMed, Embase, and Google Scholar, was carried out to gain a general understanding of Latin American and countryspecific melanoma epidemiology data and included the following terms: melanoma, skin cancer, advanced skin cancer, epidemiology, incidence, incidence rates, prevalence, prevalence rates, mortality, mortality rates, death, death rates, fatality rates, risk factors, risk variables, affected populations, ethnicity, age, clinical characteristics, sun exposure, attitudes related to sun bathing, depletion of the ozone layer, and disease burden. The first search period was 1 January 2000 to 31 December 2009. Only articles written in English were selected. The second literature search, using PubMed, LILACS, and Google Scholar, applied the same search terms to retrieve countryspecific articles, written in Spanish or Portuguese, for the period 1 January 2000 to 31 October 2010. A final search, for melanoma cases, was carried out using population-based cancer registries in the six countries. The documentation from the two literature searches and the regional cancer registry search was reviewed for relevant epidemiological information, and primary references and any additional relevant data were obtained. In the event of multiple publications containing similar information, the most recent publication and/or relevant data were used. The materials were then evaluated one by one to assess whether the studies met the above-mentioned search terms. This article summarizes the search findings. No statistical analyses were conducted.

\section{RESULTS}

\section{Worldwide incidence and mortality prevalence}

Worldwide melanoma accounts for $4 \%$ of cancer diagnoses, yet represents $75 \%$ of skin cancer-related deaths (2), with incidence and death rates increasing globally over the past few decades $(3,4)$. The five-year survival rate for patients with advanced melanoma and distant metastatic disease is $10 \%$ (5). Melanoma occurs in slightly more women than men, but mortality rates are higher for men (4). It has been observed (6) that a higher case fatality rate for melanoma has been reported in lower-income areas of the world $(57.5 \%)$ compared with higher-income areas (16.3\%). Poor melanoma survival rates have been observed in patients with low socioeconomic status (7) as well as those aged 65 years and older who resided in lower-income areas (8).

\section{Global risk factors}

Several studies (9-14) identified certain variables associated with an increased risk of developing melanoma: European ancestry, blonde and red hair, fair skin tone, light-colored eyes, the presence of freckles and/or melanocytic nevi, and family history of malignant melanoma. Other high-risk variables include a history of sunburns (14), a high number of lifetime burns (15), intermittent sun exposure, and more frequent skin exposure $(10,11)$. Some evidence $(13)$ suggests that sunburn before the age of 15 years may increase the risk of developing cutaneous melanoma (odds ratio, 2.4). However, a large meta-analysis showed the risk of melanoma may increase with the cumulative number of sunburns experienced during all periods of life (childhood, adolescence, and adulthood) and not just those experienced at a young age (15). Additional data on sun exposure throughout the lifespan are needed to further understand its effect on the development of melanoma, especially in Latin America.

\section{Country-specific incidence and mortality prevalence}

Few clinical and histopathological data on patients with melanoma are available for each Latin American country stud- ied. True incidence data are scant and generally obtained from small, singleinstitution or case-control studies that hinder comparative evaluation (16). The following section describes the available epidemiological data related to melanoma incidence and mortality rates in Argentina, Brazil, Colombia, Mexico, Puerto Rico, and Venezuela.

Argentina. Since 1990 only two cancer registries in Argentina have had epidemiological data that meet World Health Organization (WHO) International Agency for Research on Cancer (IARC) standards: the Cancer Registry of Concordia (Registro Poblacional de Tumores de Concordia, RPTC) in Entre Ríos Province, and the Regional Cancer Registry of Buenos Aires Province (Registro Regional de Tumores del Sur de la Provincia de Buenos Aires) (17). However, these data represent only a small proportion of the country's population of nearly more than 40 million (18). Recently, epidemiological melanoma data have been collected by the Argentine Cutaneous Melanoma Registry (Registro Argentino de Melanoma Cutáneo, RAMC) established by the Argentine Society of Dermatology (Sociedad Argentina de Dermatología, SAD) and the Argentine Foundation for Skin Cancer (Fundación del Cáncer de Piel, FCP). In 2010, Loria et al. (19) examined a total of 3832 melanoma cases that were registered in the RAMC over a sixyear period. The most frequent primary tumor site was the lower extremities (for women) and the trunk (for men). Patients who received their diagnosis and treatment from public health care facilities had thicker primary tumors than those who were treated at private health care centers.

In an analysis of death certification data nationwide, overall cutaneous melanoma age-adjusted mortality rates for the period from 1997 to 2001 were 1.1 per 100000 in males and 0.6 per 100000 in females (20). Argentina's melanoma mortality rates are heterogeneous, mainly because variation in skin color prevalence across different regions results in different incidence rates. For example, in the two northern provinces of Salta and Tucumán, which have a high prevalence of people of indigenous descent who have darker skin, age-adjusted mortality rates due to melanoma in men were 0.1 and 0.3 per 100000 respectively (1997-2001) (20). 
Conversely, in the capital district of Buenos Aires and Neuquén Province, in the central part of the country, which have a high prevalence of people with fair skin, age-adjusted mortality rates due to melanoma in men for the same period were much higher (1.3 and 1.2 per 100000 respectively) (20).

Brazil. The best effort to provide acceptable epidemiological data in Brazil comes from the 13-year-old populationbased Cancer Registry of Goiânia (Registro de Câncer de Base Populacional de Goiânia, RCBPG), the capital of Goiás State. The estimated annual incidence of melanoma was reported as 3.49 and 2.78 cases per 100000 habitants in men and women respectively (21). It has been observed (22) that this estimate is similar to reported incidence for other regions around the world at the same latitude. However, these data cannot be considered representative of the entire country due to its large size and geographic scope (Brazil encompasses areas above the equator and below the Tropic of Capricorn), which results in different degrees of sun exposure, and diversity of racial and ethnic patterns. A hospitalbased, cross-sectional study of 639 patients with skin cancer conducted by Ferreira et al. (23) found an overall prevalence of skin cancer of 50 cases per 100 000 inhabitants of the surrounding area (metropolitan Taubaté), with melanoma comprising $1.5 \%$ of all cases. The ratio of Caucasian to non-Caucasian inhabitants was 4:1. In other studies $(10,23-26)$, female gender and being Caucasian were predominant characteristics among skin cancer cases in Brazilian populations. Similar to what was found in Argentina, Borges et al. (27) reported the most common site for melanoma was the trunk (in men) and the lower limbs (in women). A retrospective epidemiological study (24) described the clinical and histopathological variables of cutaneous melanoma and its correlations. The majority of the 364 cases analyzed presented with thick and ulcerated tumors, denoting late diagnosis and poor prognosis.

Mendes et al. (28) analyzed melanoma mortality rates for all regions of Brazil from 1980 to 2005 for the entire population with respect to age, gender, and geographical patterns of distribution using data provided by the National Mortality System (Sistema de Informação sobre Mortalidade, SIM). The annual average percentage change (AAPC) in mortality related to melanoma was $1.1 \%$ for the entire country during that time period. Mortality was the highest in elderly individuals, and mortality rates were higher in the South and Southeast regions (1.24 and 0.72 deaths per 100000 inhabitants respectively) (28).

Colombia. Time trends from the Cali Cancer Registry (El Registro de Cáncer de Cali, RPCC), Colombia's only population-based cancer registry to date, showed that average annual melanoma incidence increased from 1.6 and 1.0 to 3.5 and 3.2 in men and women respectively between 1966 and 2007 (29). Data from the institutional registry of the Federico Lleras Acosta Dermatological Centre (Centro Dermatológico Federico Lleras Acosta, CDFLLA) (30) showed that melanoma increased from 2.7 cases per 10000 to 13 cases per 10000 from 2003 to 2005. The National Cancer Institute in Bogotá (Instituto Nacional de Cancerología, INC) reported that malignant melanoma was the main cause of dermatological disease death (40\%), comprising $1 \%$ of total cancer deaths (31). The mean age at presentation for melanoma has been reported as 58 years and the survival rate has been shown to be lower among the black population from the Pacific Region, partly due to delayed diagnoses (32).

Mexico. In 2003, the most recent year for which data are available, Mexico's Histopathologic Cancer Registry (Registro Histopatológico de Neoplasias Malignas, RHNM) reported a total of 14319 cases of skin cancer, of which 9.02\% (1 293 new cases) corresponded to melanoma (33). Melanoma mortality represented 377 cases or 0.4 per 100000 inhabitants (34). The latest report from the Melanoma Clinic at Mexico's National Cancer Institute (Instituto Nacional de Cancerologia, INCan) (35) noted that incidence of melanoma increased during 1990 to 2004, and was more prevalent in women $(57.1 \%)$, and the mean age at presentation was 54.3 years. RuizMaldonado et al. (36) analyzed four hospital-based studies that revealed the most common primary tumor site was the lower extremities. Additional publications support these findings (37).

Puerto Rico. A retrospective study of all melanoma cases reported to the Puerto
Rico Central Cancer Registry (El Registro Central de Cáncer de Puerto Rico, PRCCR) from 1987 to 2002 (38) revealed 1568 new melanoma cases, with a mean of 98 new cases per year. The annual age-adjusted incidence and mortality rates were 1.9 (men) to 3.6 (women) and 0.3 (men) to 0.7 (women) respectively per 100000 inhabitants. The majority of reported cases among both men and women were 61 to 80 years of age, with an equal percentage of men and women affected. Consistent with what was seen in other Latin American countries, the most common anatomical location was the lower extremities (in women) and the trunk (in men).

Venezuela. To date, there are few population-based studies reporting melanoma incidence rates and no reliable registry data reporting melanoma mortality rates for Venezuela $(39,40)$. However, the Venezuela Cancer Registry (Registro Nacional de Cáncer de Venezuela, RNCV) created an electronic Internet version of a database originally established by the Multidisciplinary Group on Melanoma Study (Grupo Multidisciplinario y Multicéntrico para el Estudio del Melanoma, GMMM) in 2004 for the cities of Caracas and Valencia as part of a pilot project (41). The database categorizes patient cases based on clinical and histological characteristics, surgeries performed, and adjuvant treatment. The seven-year pilot project currently has three Venezuelan institutions (with nine medical centers) as registered users. In December of 2009, according to data from GMMM (41), there were 701 patients in the database; of these, $54.9 \%$ were women, and the median age of presentation was 56 years. The annual reported number of skin cancer cases was 116. Fifty-seven percent $(57 \%)$ of the patients with melanoma had a previous history of sunburn. The most frequent localization site for primary melanoma was the limbs $(53.2 \%)$, followed by the trunk (32\%) and the head and neck areas (14.8\%). Most cases were recorded as invasive melanoma (84.4\%).

\section{Geography- and patient-related risk factors}

Although consistent data related to the incidence, prevalence, and mortality rates of melanoma are lacking in Latin America, the risk of developing melanoma appears to be associated 
with individual patient characteristics and geographic location within the region (i.e., environmental conditions). In some Latin American countries, it has been reported $(42,43)$ that the number of acral lentiginous melanoma cases is higher than may be expected due to the high percentage of indigenous ancestry among the population.

Argentina. Argentina spans a vast territory and has relatively heterogeneous provinces due to a historically diverse immigration flow. Considerable portions of the population are descendants of both European and native inhabitants, resulting in different genotypes and phenotypes nationwide. A survey of indigenous groups (44) estimated that 600329 Amerindians are largely distributed in the Northeast, Northwest, and Patagonia regions. Similar to what was found in other countries in the region, case-control studies $(9,13)$ reported various individual characteristics associated with an increase risk of melanoma, including fair skin tone, light eye color, and European ancestry.

Brazil. Several authors $(10,11)$ have reported that the skin color of the Brazilian population is generally darker in people who reside close to the equator and lighter in those living in the southern region of the country, which is largely populated by European descendants. As seen in the Argentine population, individuals in the southern region with European (particularly German) ancestry have the highest estimated incidence of cutaneous malignant melanoma compared with individuals from other parts of the country $(10,20)$. Other individual characteristics related to the development of melanoma in the southern Brazilian population, according to research (10), were light-colored hair and eyes.

Colombia. Few melanoma studies have evaluated the populations at-risk for melanoma in Colombia. In a retrospective study, Villegas et al. (45) found the highest prevalence of malignant melanoma among Caucasian women, who presented the disease at a median age of 60 years. Researchers also found that two-thirds of the patients with skin cancer were from urban areas, with the remaining third residing in rural areas with limited access to health care services. Most of the patients diagnosed with melanoma and other skin tumors were from low socioeconomic means and used the social security health system.

Mexico. No studies have been conducted to determine the effect of melanoma in either the general Mexican population or among Mexico's at-risk ethnic groups. Racial heterogeneity is higher in both Mexico and Central America than in South American countries. As of 2010, the Mexican population had reached approximately 112 million, with $76.5 \%$ residing in urban areas (46). In Mexico, it has been reported (46) that mestizos (people of mixed indigenous and Caucasian descent) account for approximately threefifths of the population. Pure-blooded indigenous people account for less than one-third of the population. Those of Caucasian descent constitute the remaining population, with Mexicans of African descent representing a tiny fraction of this population. Areas such as Zacatecas State span the Tropic of Cancer and have elevations of 1800 to 2250 meters above sea level (i.e., areas of high sun exposure) (46). A population-based study (47) from Zacatecas State found a higher proportion of women with confirmed cases of melanoma versus men, but no ethnic profiling was obtained.

Puerto Rico. Puerto Rico covers an area of 3500 square miles, and most of its population lives at sea level, making it challenging to quantify geographic trends related to melanoma and the ethnic populations inhabiting the island. The population has been shaped by Amerindian settlement, European colonization, slavery, economic migration, and its status as a U.S. Commonwealth (48). The specific risk factors for melanoma in the Puerto Rican population are still unknown. In 2004, the PRCCR reported males aged 20 to 34 years were at high risk for melanoma (49).

Venezuela. Venezuela is a country of great racial diversity. The majority of the current population is mestizo, with the remainder mainly of European (primarily German, Italian, Portuguese, or Spanish) descent (50). Blacks account for an estimated $8 \%$ to $10 \%$ of the population, and Amerindians represent about 2\%. Arabs also represent part of the overall populace (50). Based on data from GMMM (41), the majority of patients with melanoma had fair skin tone and light-colored eyes, and those with light skin had relatively high levels of pigmentation (skin phototype III).

\section{Environmental variables related to disease burden}

Dramatic changes in the Earth's ozone have been reported since the late 1980s (51). In the Southern Hemisphere, the increase in ultraviolet (UV) radiation has been estimated at 5\% per decade at 30 degrees south to $40 \%$ per decade at 85 degrees south (51). Fifteen percent (15\%) of the ozone layer has been depleted over the southern end of South America during the past 15 years, and an increase of up to $85 \%$ in UV-B radiation in the southern part of Chile has been observed $(52,53)$. Corrêa et al. (54) reported that cities in high-altitude areas are at risk for dangerous levels of exposure to UV radiation. For each 1 000-meter increase in altitude, UV radiation increases by $6 \%$ to $8 \%$. Many populated areas in Latin America are at higher elevations (e.g., La Paz, Bolivia, the highest-altitude capital city in the world, and São Paulo, Brazil, one of the most highly populated cities in South America). Furthermore, in recent decades, it has been observed (55) that the use of ozone-destroying chemicals has caused the thinning of the ozone layer, which worsens the effects of sun overexposure. In the Southern Hemisphere, the ozone layer normally thins each spring. Several reports $(52,55)$ have noted that ozone depletion in an area above the southern portion of Argentina and Chile causes a $25 \%$ increase in UV radiation exposure during this time of the year. UV radiation in the Southern Hemisphere is expected to worsen in the coming decades due to natural variations in the amount of ozone circulating in the upper atmosphere (52). In Antarctica, the hole in the Earth's ozone layer expanded to 27.5 million $\mathrm{km}^{2}$ in September 2006 (55). A greater incidence of cutaneous melanoma has been found among populations living under the Antarctic ozone hole (southern Chile) and in the south of Brazil $(54,56)$ compared to people who live in regions where there is no ozone hole (20) or only reside in ozone-depleted areas during seasons of the year when the ozone hole is smaller (56). Although the causality of this relationship cannot be determined because these studies did not control for confounding variables, the evidence 
supports the link between increased UV exposure and increased melanoma risk.

\section{Health care limitations affecting disease burden}

Variables in delay of melanoma diagnosis. Despite the known risks of overexposure to UV rays, several authors $(57,58)$ have reported the common worldwide view that tanned skin is attractive, healthy, and protects against future burns. Many individuals do not view intentional tanning outdoors or at indoor tanning booths as a health risk $(57,58)$. In fact, there is a relatively high frequency of sunbathing and tanning bed use among youth $(58,59)$. A population-based, cross-sectional study of 1412 Brazilians aged 10 to 29 years (60) found that nearly half of the patients enrolled in the study were sunburned in the past year. A similar study of 3136 Brazilian adults (61) found that individuals who had the greatest sun exposure were the least likely to use sunscreen. Sunscreen users were typically female, Caucasian, and had a high level of education or high socioeconomic status.

In many parts of Latin America, geographic or financial constraints can impede patient access to basic health care. Frequent visits to the physician increase the likelihood that patients will be diagnosed with melanoma at an early stage-when the lesions are still thin (62). However, access to health care in many regions of Latin America is often limited $(24,33,45)$. Villegas et al. (45) examined a mixed population from the Andean region in Colombia and concluded that patients experienced a median time of 243.5 days between lesion detection and evaluation by a dermatologist. Delayed melanoma diagnosis was associated with being female, older than 65 years of age, and living in a rural setting. In Argentina, González et al. reported that patients without private health insurance and those without any health insurance were more likely to be diagnosed with more advanced stages of melanoma. ${ }^{7}$ Studies in other regions have shown that socioeconomic

\footnotetext{
González A, Cinat G, Chapela J, Del Aguila R, Sokol G, Otero JA. Association of insurance status with cutaneous melanoma (CM) stage at diagnosis. Poster presented at the 7 th World Congress on Melanoma and 5th Congress of the European Association of Dermato-Oncology; May 12-16, 2009; Vienna, Austria.
}

status influences diagnosis time for a variety of medical conditions. The racial and geographic diversity of the Latin American population makes establishing a similar correlation difficult. This correlation should be studied in future research.

Knowledge of melanoma. Knowledge about the importance of early detection varies worldwide. A study by Blum et al. (63) assessed factors that delay diagnosis in Australia, Brazil, Germany, and Sweden. Investigators found that about $62 \%$ of patients from Brazil detected the lesion themselves, a higher percentage than that found in other countries (52\%$59 \%)$. Overall, more women than men detected lesions on their own. Compared with the other countries, people in Brazil had the lowest awareness of the importance of early detection (63). Furthermore, most people from Brazil received their knowledge about melanoma from the media, with few citing physicians as their source of information, and an even smaller number citing prevention campaigns.

Although official (national) public health policies for melanoma diagnosis and treatment have been published in most countries in the region, the information contained within them varies, resulting in inconsistent public awareness messages regarding melanoma.

\section{Regional melanoma management and awareness}

Melanoma awareness initiatives (i.e., screening and detection campaigns) have shown varying degrees of success and acceptance in countries that showed an increase in the incidence of skin cancer over the past decade (64-67). In some Latin American countries, private nonprofit organizations such as Venezuela's Anti-cancer Society (Sociedad Anticancerosa de Venezuela, SAV), the CDFLLA in Colombia, the Brazilian Society of Dermatology (Sociedade Brasileira de Dermatologia, SBD), and the FCP and SAD in Argentina are key players in carrying out annual nationwide melanoma detection campaigns $(64-66,68)$. For the past 17 years, the SAD has held annual melanoma detection campaigns, with a yearly increase in attendance. In Brazil, in 2008, more than 40000 people attended the annual National Campaign to Prevent Skin Cancer (Campanha Nacional de Prevenção do Câncer da Pele), and skin lesions were found in $10 \%$ of attendees (66).

Screening for melanoma is a controversial topic because its effectiveness in increasing survival has not been established (69). Consequently, governments and other agencies may not be willing to invest in widespread screening campaigns. However, mass media screening campaigns have been found useful in targeting high-risk groups. Thus, additional efforts would invariably aid in advanced melanoma management (69).

\section{DISCUSSION}

To the best of the authors' knowledge, this is the first literature review to summarize the published and available melanoma incidence and mortality data for the Latin American countries of Argentina, Brazil, Colombia, Mexico, Puerto Rico, and Venezuela. The importance of reporting the true incidence and mortality rates of melanoma cannot be overstated. Argentine, Brazilian, and Puerto Rican specialists have conducted more studies that report incidence data compared with researchers in the three other countries. Mexico, Venezuela, and Colombia have performed only a few population-based or case-control studies describing melanoma in their populations.

Cancer registries are essential for collecting and gathering accurate epidemiological information related to melanoma. All six countries have cancer registries that, to some degree, regularly collect and report new cases of melanoma. However for the most part, the data from the country-specific cancer registries are limited in terms of the variables collected, are regionalized, and represent only a small fraction of the actual melanoma incidence rates, as many people remaining undiagnosed. Although melanoma mortality rates are usually captured and reported in these registries, the data collection is not efficient, and there is no standard method of collection, making comparisons between regions and countries difficult. While dermatological societies and multidisciplinary academic groups have encouraged specialists to enter melanoma data in their databases, this information represents only a small fraction of true melanoma incidence in the general population of each country. In addition, investigators and researchers have limited resources and therefore have not published a sufficient amount 
of data for local and international appraisal. The main impediments to establishing and maintaining an accurate epidemiological database for the countries studied in this review are underreporting of melanoma and the lack of a centralized collection system. Legislation tailored to each country's specific type of health system could help researchers obtain more accurate epidemiological data. Each country has unique needs and challenges in containing melanoma, and much work is needed to improve outcomes.

The lack of reliable epidemiological data for Latin America limits the degree of melanoma awareness in the region. Having an accurate, centralized melanoma registry could facilitate more effective educational programs and improve health care planning. Additional studies elucidating the etiology and risk factors for melanoma among minority populations are also warranted. Unfortunately, the heterogeneity of the health care systems in Latin American countries makes it difficult to establish a supranational cooperative system for data gathering in melanoma as well as other diseases.

People in certain strata of Latin American populations appear to have a greater awareness of melanoma than others (45). Increased awareness (along with changes in the registration process) may help ex- plain the recent increase in melanoma cases shown in some of the countryspecific cancer registries. Awareness campaigns are best targeted to those with limited access to health care, who would benefit the most.

As melanoma treatment evolves, Latin American governments and regulatory health care agencies will face the challenge of adjusting policies and reimbursement guidelines to allow patient access to better care. Key policy-makers must recognize melanoma as a serious cancer and give priority to melanoma management.

\section{Limitations}

This review was limited by the small amount of published and available incidence and mortality data for Latin America. In addition, the data derived from the cancer registries were relatively sparse, may not be representative of the general population, and covered only short periods, and a large proportion of the information obtained in the literature review came from studies conducted in hospitals, health care facilities and institutions, and cancer registries with different methods of data collection and no uniformity in data reporting, which hindered comparative evaluation and precluded meaningful statistical analy- sis. Finally, in an attempt to cover a larger geographic area and compare different strategies across the region (with less discrepancies in terms of methodology and technical resources), the authors limited the first and second search periods to the years 2000 through 2009 and 2010 respectively.

\section{Conclusion}

Melanoma is a serious and life-threatening public health problem in Latin America. Although attempts have been made to collect melanoma epidemiologic data for Latin American countries and disseminate information about the risk factors, these efforts are not yet sufficient. Environmental factors such as the effects of the ozone layer and individual factors such as mixed ethnicity could be better explored and compared with other regions of the world if solid epidemiological data were available. These data could also facilitate improvements in health care planning. Increased melanoma awareness could lead to better health care for individuals as well as the general populations of countries in the region.

Acknowledgments. Editorial support for the preparation of this manuscript was provided by Michelle A. Adams of Write All, Inc.

\section{REFERENCES}

1. American Cancer Society. Cancer facts \& figures 2010. Atlanta: ACS; 2010.

2. Brady MS, Kaushal A, Ko C, Flaherty K. Chapter 20: Melanoma and other skin cancers. In: Pazdur R, Wagman LD, Camphausen KA, Hoskins WJ, editors. Cancer management: a multidisciplinary approach: medical, surgical \& radiation oncology. 12th ed. Norwalk, CT: CMP Medica; 2009. Pp. 1-24.

3. de Vries E, Coebergh JW. Cutaneous malignant melanoma in Europe. Eur J Cancer. 2004;40(16):2355-66.

4. Parkin DM, Bray F, Ferlay J, Pisani P. Global cancer statistics, 2002. CA Cancer J Clin. 2005; 55(2):74-108.

5. Balch CM, Soong SJ, Gershenwald JE, Thompson JF, Reintgen DS, Cascinelli N, et al. Prognostic factors analysis of 17,600 melanoma patients: validation of the American Joint Committee on Cancer melanoma staging system. J Clin Oncol. 2001;19(16):3622-34.

6. Beaulieu N, Bloom D, Bloom R, Stein R. Breakaway: the global burden of cancer- challenges and opportunities. London: The Economist Intelligence Unit; 2009.

7. Zell JA, Cinar P, Mobasher M, Ziogas A, Meyskens FL Jr, Anton-Culver H. Survival for patients with invasive cutaneous melanoma among ethnic groups: the effects of socioeconomic status and treatment. J Clin Oncol. 2008;26(1):66-75.

8. Reyes-Ortiz CA, Goodwin JS, Freeman JL, Kuo YF. Socioeconomic status and survival in older patients with melanoma. J Am Geriatr Soc. 2006;54(11):1758-64.

9. Lascano AR, Kuznitzky R, Cuestas E, Mainardi C, Albertini R, Borello A, et al. Factores de riesgo para melanoma cutáneo. Estudio de casos y controles en Córdoba, Argentina. Medicina (Buenos Aires). 2004; 64(6):504-8.

10. Bakos L, Wagner M, Bakos RM, Liete CS, Sperhacke CL, Dzekaniak KS, et al. Sunburn, sunscreens, and phenotypes: some risk factors for cutaneous melanoma in southern Brazil. Int J Dermatol. 2002;41(9):557-62.
11. Bakos L, Masiero NC, Bakos RM, Burttet RM, Wagner MB, Benzano D. European ancestry and cutaneous melanoma in Southern Brazil. J Eur Acad Dermatol Venereol. 2009; 23(3):304-7.

12. Crombie IK. Racial differences in melanoma incidence. Br J Cancer. 1979;40(2):185-93.

13. Loria D, Matos E. Risk factors for cutaneous melanoma: a case-control study in Argentina. Int J Dermatol. 2001;40(2):108-14.

14. Veierød MB, Weiderpass E, Thörn M, Hansson J, Lund E, Armstrong B, et al. A prospective study of pigmentation, sun exposure, and risk of cutaneous malignant melanoma in women. J Natl Cancer Inst. 2003;95(20):1530-8.

15. Dennis LK, Vanbeek MJ, Beane Freeman LE Smith BJ, Dawson DV, Coughlin JA. Sunburns and risk of cutaneous melanoma: does age matter? A comprehensive meta-analysis. Ann Epidemiol. 2008;18(8):614-27.

16. World Health Organization. WHO Cancer mortality database [Internet]. Lyon (France): IARC/WHO; c2010. Available from: http:// 
www-dep.iarc.fr/WHOdb/WHOdb.htm Accessed 4 December 2010.

17. Ferlay J, Parkin DM, Curado MP, Bray F, Edwards B, Shin HR, et al. Cancer incidence in five continents, volumes I to IX: IARC CancerBase no. 9 [Internet]. Lyon (France): International Agency for Research on Cancer; 2010. Available from: http://ci5.iarc.fr/CI5iix/ci5i-ix.htm Accessed 6 December 2010.

18. Argentina country profile [Internet]. London: BBC; c2011. Available from: http:// news.bbc.co.uk/2/hi/americas/country_ profiles/1192478.stm\#facts Accessed 14 September 2011.

19. Loria DI, González A, Latorre C. Epidemiología del melanoma cutáneo en Argentina: análisis del Registro Argentino de Melanoma Cutáneo. Dermatol Argent. 2010;16(1):39-45.

20. Matos EL, Loria DI, editors. Atlas de mortalidad por cáncer: Argentina 1997-2001. Buenos Aires: Bunge y Born Foundation; 2003. Available from: http://www.asarca.org.ar/ archivos/AtlasMortalidadCancerArg97-01. pdf Accessed 22 March 2011.

21. Sortino-Rachou AM, Curado MP, Latorre MRDO. Melanoma cutâneo: estudo de base populacional em Goiânia, Brasil, de 1988 a 2000. An Bras Dermatol. 2006;81(5):449-55.

22. Green A, Battistutta D, Hart V, Leslie D, Weedon D. Skin cancer in a subtropical Australian population: incidence and lack of association with occupation. The Nambour Study Group. Am J Epidemiol. 1996; 144(11):1034-40.

23. Ferreira FR, Nascimento LFC. Câncer cutâneo em Taubaté (SP) - Brasil, de 2001 a 2005: um estudo de prevalência. An Bras Dermatol. 2008;83(4):317-22.

24. Ferrari NM Jr, Muller H, Ribeiro M, Maia M, Sanches JA Jr. Cutaneous melanoma: descriptive epidemiological study. Sao Paulo Med J. 2008;126(1):41-7.

25. Gon AS, Minelli L, Guembarovski AL. Melanoma cutâneo primário em Londrina. An Bras Dermatol. 2001;76(4):413-26.

26. Lapa MS, Guedes KF, Schalch FO, Landman G. Melanomas malignos cutâneos tratados no Hospital do câncer de São Paulo: estudo retrospectivo para avaliação de distribuição, fatores prognósticos e sobrevida. An Bras Dermatol. 2002;77(3):313-20.

27. Borges SZ, Bakos L, Cartell A, Wagner M, Agostini A, Lersch E. Distribution of clinical-pathological types of cutaneous melanomas and mortality rate in the region of Passo Fundo, RS, Brazil. Int J Dermatol. 2007;46(7):679-86

28. Mendes GL, Koifman RJ, Koifman S. Mortality frequency and trends attributed to melanoma in Brazil from 1980-2005. J Toxicol Environ Health A. 2010;73(13-14):850-7.

29. Cali Cancer Registry. C43 melanomas: average annual age-specific incidence rates, crude rates (all ages) and age-standardized rates (ASR) by sex in Cali, Colombia from 1962 through 2007 [Internet]. Cali: Universidad del Valle; c2010. Available at: http:// rpcc.univalle.edu.co/in/SitiosEspecificos/ pdf-sitiosespecificos/Sitios_Especificos. php?sitio=8 Accessed 4 January 2011.

30. Nova-Villanueva J, Sánchez-Vanegas G, Porras de Quintana L. Cáncer de piel: perfil epidemiológico de un centro de referencia en Colombia 2003-2005. Rev Salud Publica. 2007;9(4):595-601.

31. Pardo C, Murillo R, Piñeros M, Castro MA. Casos nuevos de cáncer en el Instituto $\mathrm{Na}$ cional de Cancerología, Colombia, 2002. Rev Colomb Cancerol. 2003;7(3):4-19.

32. Colmenares LM, Velásquez M, Vargas GA. Melanoma lentiginoso acral: una variante de melanoma malign de especial interés en Colombia. Iatreia. 2008;21(4):386-97.

33. Secretaría de Salud (MX). Registro Histopatológico de Neoplasias Malignas. Ed. 2003. In: Cáncer de piel. México, DF: Secretaría de Salud; c2011

34. Secretaría de Salud (MX). Registro Histopatológico de Neoplasias Malignas. Ed. 2003. In: Mortalidad por tumores malignos. México, DF: Secretaría de Salud; c2011.

35. Martínez-Saíd H, Cuellar-Hubbe M, Barrón Velásquez E, Padilla RA, Herrera-Gómez A, López Graniel CM, et al. Epidemiology of cutaneous melanoma in Mexico (1980-2002). Eur J Surg Oncol. 2004;30(2):163.

36. Saez-de-Ocariz M, Sosa-de-Martínez C, Duran-McKinster C, Orozco-Covarrubias L, Palacios-López C, Ruiz-Maldonado R, et al. Cutaneous melanoma in private vs. public practices of Mexican dermatologists. Int J Dermatol 2008;47(6):637-9.

37. Alfeirán Ruiz A, Escobar Alfaro G, de la Barreda Becerril F, Herrera Gómez A, Padilla Rociano A, Suchil Bernal L. Epidemiología del melanoma de piel en México. Rev Inst Nal Cancerol (Mex). 1998;44(4):168-74.

38. Valentín SM, Sánchez JL, Figueroa LD, Nazario CM. Epidemiology of melanoma in Puerto Rico, 1987-2002. P R Health Sci J. 2007;26(4):343-8.

39. Capote Negrin LG. Aspectos epidemiológicos del cáncer en Venezuela. Rev Venez Oncol. 2006;18(4):269-81.

40. Gonzáles R, Ramos W, Borges Garnica A, Vegas I, Uzcategui N, Moequera J, et al. Análisis multifactorial del melanoma maligno: experiencia del Instituto de Oncología Dr. Miguel Pérez Carreño. Rev Venez Oncol. 2004;16(3):144-9.

41. Grupo Multidisciplinario y Multicéntrico para el Estudio del Melanoma (VE). Valencia: GMMM; c2010. Available from: http:/ / www. gmmm.com.ve/ Accessed 8 December 2010.

42. Rollano F, Encinas S, Monasterios H, Parra E, Valda L. Melanoma maligno, estudio epidemiológico de 85 casos. Rev Boliviana Dermatol. 2002;1(1):7-10.

43. Zegarra del Carpio R. Situación del melanoma maligno cutáneo en el Hospital Military Central Lima 1985-2007. Dermatol Peru. 2008;18(3):267-83.

44. Instituto Nacional de Estadísticas y Censos (AR). Encuesta Complementaria de Pueblos Indígenas (ECPI) [Internet]. Buenos Aires: INEC; c2010. Available from: http://www. indec.gov.ar/webcenso/ECPI/index_ecpi. asp Accessed 3 December 2010.

45. Mesa Villegas JI, Jaramillo Ayerbe F, Benjumea Rincón MV. Factores relacionados con la consulta tardía a dermatología por cáncer de piel: prueba piloto: Departamento de Caldas. Hacia Promoc Salud. 2008;13(1): $178-94$.
46. Instituto Nacional de Estadística y Geografía (MX) [Internet]. Aguascalientes, AG: INEGI; c2010. Available from: http:/ / www.inegi.org. mx/default.aspx Accessed 8 December 2010.

47. Pinedo JL, Castañeda R, McBride LE, Dávila JI, Mireles F, Ríos C. Estimates of the skin cancer incidence in Zacatecas, México. Open Dermatol J. 2009;3:58-62.

48. Encyclopedia of the Nations. Americas: Puerto Rico [Internet]. Flossmoor, IL: Advameg Inc.; c2010. Available from: http:// www.nationsencyclopedia.com/economies/ Americas/Puerto-Rico.html Accessed 15 December 2010 .

49. Figueroa-Vallés NR, De la Torre-Feliciano T, Ortiz-Ortiz KJ, Pérez-Irizarry J, TorresCintrón M, editors. Cancer in Puerto Rico 2004: cancer incidence and mortality. San Juan (Puerto Rico): Puerto Rico Central Cancer Registry; 2010.

50. Encyclopedia of the Nations. Americas: Venezuela [Internet]. Flossmoor, IL: Advameg Inc.; c2010. Available from: http://www.nations encyclopedia.com/Americas/Venezuela. html Accessed 15 December 2010.

51. Madronich S, Björn LO, Ilyas M, Caldwell MM. Changes in biologically active ultraviolet radiation reaching the Earth's surface. In: van der Leun JC, Tevini M, Worrest RC, editors. Environmental effects of ozone depletion: 1991 Update. Nairobi: United Nations Environment Programme; 1991. Pp.1-13.

52. Munro M. UV radiation to rise 20 percent, scientists warn [Internet]. Ottawa Citizen. 7 Sept 2009. Available from: http://www.atmosp. physics.utoronto.ca/C-SPARC/publicity/ UVrising.pdf Accessed 22 March 2011.

53. Ministerio de Salud (CL). Riesgos de la radiación ultraviolet en la salud de las personas. Santiago: MINSAL, Unidad de Cáncer; 2008.

54. Corrêa MP, Dubuisson P, Plana-Fattori A. An overview of the ultraviolet index and the skin cancer cases in Brazil. Photochem Photobiol. 2003;78(1):49-54.

55. Estrada D. UV radiation, the dark side of the sun. IPS Environment [Internet]. 9 Jan 2009 Available from: http://ipsnews.net/print asp?idnews=36104 Accessed 22 March 2011.

56. Abarca JF, Casiccia CC. Skin cancer and ultraviolet- $\mathrm{B}$ radiation under the Antarctic ozone hole: southern Chile, 1987-2000. Photodermatol Photoimmunol Photomed. 2002;18(6): 294-302.

57. Robinson JK, Rigel DS, Amonette RA. Trends in sun exposure knowledge, attitudes, and behaviors: 1986 to 1996. J Am Acad Dermatol. 1997;37(2 Pt 1):179-86.

58. Rhainds M, De Guire L, Claveau J. A population-based survey on the use of artificial tanning devices in the Province of Québec, Canada. J Am Acad Dermatol. 1999; 40(4):572-6.

59. Melia J, Bulman A. Sunburn and tanning in a British population. J Public Health Med. 1995; 17(2):223-9.

60. Haack RL, Horta BL, Cesar JA. Queimadura solar em jovens: estudo de base populacional no Sul do Brasil. Rev Saude Publica. 2008; 42(1):26-33.

61. Duquia RP, Baptista Menezes AM, Reichert FF, de Almeida HL Jr. Prevalence and associated factors with sunscreen use in Southern 
Brazil: a population-based study. J Am Acad Dermatol. 2007;57(1):73-80.

62. Di Quinzio ML, Dewar RA, Burge FI, Veugelers PJ. Family physician visits and early recognition of melanoma. Can J Public Health. 2005; 96(2):136-9.

63. Blum A, Ingvar C, Avramidis M, von Kannen A, Menzies SW, Olsson $\mathrm{H}$, et al. Time to diagnosis of melanoma: same trend in different continents. J Cutan Med Surg. 2007;11(4): 137-44.

64. Goihman-Yahr M. Sun education in Venezuela. Clin Dermatol. 1998;16(4):522-3.
65. Kenyon G. Experts call for urgent skin-cancer awareness campaigns in Chile. Lancet Oncol. 2009;10(4):319-20.

66. From Australia to Brazil: sun worshippers beware. Bull World Health Organ. 2009;87(8): 574-5.

67. Sociedad Argentina de Dermatología. Campañas [Internet]. Buenos Aires: SAD; c2010. Available from: www.sad.org.ar Accessed 26 December 2010.

68. Sociedad Argentina de Dermatología. 17th Campaña Nacional de Prevención del Cáncer de Piel [Internet]. Buenos Aires: SAD; c2010. Available from: http://www.cancerde piel.org.ar/index.html Accessed 26 December 2010.

69. Stratigos AJ, Katsambas AD. The value of screening in melanoma. Clin Dermatol. 2009; 27(1):10-25.

Manuscript received on 28 January 2011. Revised version accepted for publication on 19 June 2011.

RESUMEN Objetivo. Identificar la literatura científica sobre el melanoma cutáneo en América Latina y recopilar todos los datos epidemiológicos disponibles, con objeto de demostrar la necesidad de información fiable a escala regional y de país sobre los datos de incidencia y mortalidad.

El melanoma cutáneo en América Latina: la necesidad de más datos

Palabras clave
Métodos. Se realizaron búsquedas bibliográficas en las bases de datos PubMed, Embase, LILACS y Google Scholar para encontrar estudios epidemiológicos relacionados con el melanoma llevados a cabo del 1 de enero del 2000 al 31 de octubre del 2010 en Argentina, Brasil, Colombia, México, Puerto Rico y Venezuela. Se efectuó una búsqueda final de casos de melanoma mediante la consulta de los registros poblacionales de cáncer de cada país. No se realizó ningún análisis estadístico.

Resultados. En los seis países, la mayor parte de la investigación epidemiológica sobre el melanoma cutáneo consiste en estudios hospitalarios o estudios de casos y testigos. Muy pocos estudios informan sobre las tasas de incidencia y mortalidad. Los intentos de calcular las tasas de la enfermedad se han basado en los datos nacionales de incidencia y mortalidad, y en la información extraída de los registros de cáncer. Aunque el predominio de la ascendencia europea constituye un conocido factor de riesgo de melanoma, la asociación entre el melanoma y el grupo étnico no puede demostrarse adecuadamente en algunas de las poblaciones estudiadas. Los latinoamericanos están frecuentemente expuestos a la radiación ultravioleta como consecuencia del clima tropical, la elevada altitud y la disminución de la capa de ozono en algunas regiones. La piel bronceada se considera como saludable y bella. Aunque hace decenios que se llevan a cabo campañas de salud pública dedicadas al melanoma en América Latina, es indispensable incrementar la conciencia de esta enfermedad.

Conclusiones. Existe la urgente necesidad de recopilar datos epidemiológicos precisos sobre el melanoma en América Latina. Las futuras actividades de investigación en la Región deben incluir un mayor número de estudios poblacionales extensos y específicos de cada país, que permitan evaluar comparativamente las tasas de incidencia y mortalidad.

Melanoma; neoplasias cutáneas; sistemas de información; mortalidad; incidencia; riesgo; Argentina; Brasil; Colombia; México; Puerto Rico; Venezuela; América Latina. 